\title{
Cholesterol Information and Shell Egg Consumption
}

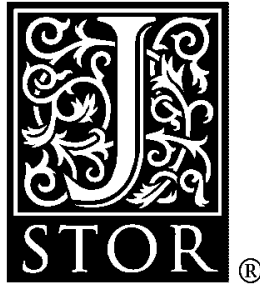

\author{
Deborah J. Brown; Lee F. Schrader
}

American Journal of Agricultural Economics, Vol. 72, No. 3. (Aug., 1990), pp. 548-555.

Stable URL:

http://links.jstor.org/sici?sici=0002-9092\%28199008\%2972\%3A3\%3C548\%3ACIASEC\%3E2.0.CO\%3B2-F

American Journal of Agricultural Economics is currently published by American Agricultural Economics Association.

Your use of the JSTOR archive indicates your acceptance of JSTOR's Terms and Conditions of Use, available at

http://www.jstor.org/about/terms.html. JSTOR's Terms and Conditions of Use provides, in part, that unless you have obtained prior permission, you may not download an entire issue of a journal or multiple copies of articles, and you may use content in the JSTOR archive only for your personal, non-commercial use.

Please contact the publisher regarding any further use of this work. Publisher contact information may be obtained at http://www.jstor.org/journals/aaea.html.

Each copy of any part of a JSTOR transmission must contain the same copyright notice that appears on the screen or printed page of such transmission.

The JSTOR Archive is a trusted digital repository providing for long-term preservation and access to leading academic journals and scholarly literature from around the world. The Archive is supported by libraries, scholarly societies, publishers, and foundations. It is an initiative of JSTOR, a not-for-profit organization with a mission to help the scholarly community take advantage of advances in technology. For more information regarding JSTOR, please contact support@jstor.org. 


\title{
Cholesterol Information and Shell Egg Consumption
}

\author{
Deborah J. Brown and Lee F. Schrader
}

\begin{abstract}
U.S. per capita shell egg consumption has declined steadily since 1955 despite a falling real price. This paper investigates how information about cholesterol, as measured by a newly constructed index based on medical journal articles, has affected U.S. demand for shell eggs. The results of a fixed coefficient model indicate that information on the links between cholesterol and heart disease had decreased per capita shell egg consumption by $16 \%$ to $25 \%$ by the first quarter of 1987 . A simple changing coefficient model indicates that cholesterol information has changed shell eggs' own price and income elasticities, so that the 1955-87 falling egg price and rising income increased egg consumption less than they otherwise would have.
\end{abstract}

Key words: cholesterol, demand analysis, eggs, health information.

U.S. per capita shell egg consumption has declined steadily since 1955 despite a large downward trend in real price. One suggested reason for the decline is increasing consumer concern with the cholesterol content of eggs (Putler, Schrader et al., Stillman). However, this issue has received little empirical investigation except for Putler's diffusion process model. Putler modeled the effect of cholesterol information on egg consumption by including a nonlinear function of time in the demand equation. ${ }^{1}$ He concluded that cholesterol information first had an effect in the second quarter of 1969 and had reduced egg consumption by approximately $14 \%$ by the fourth quarter of 1980 , with no further reductions between 1980 and 1985 .

Time trends long have been used to account for changes in consumer tastes (Stone). More specific data on consumers' changing tastes are difficult to obtain. In the case of eggs, however, one can go beyond a time trend variable to con-

Deborah J. Brown is an associate professor, and Lee F. Schrader is a professor, Department of Agricultural Economics, Purdue University.

The authors would like to thank James K. Binkley, B. Wade Brorsen, and several anonymous referees for helpful comments on earlier drafts; Louis B. Raffel, of the American Egg Board, for copies of portions of their attitude-tracking surveys; and Mark Weiner, of the U.S. Department of Agriculture, for unpublished egg price data.

'The term in Putler's demand equation is $\exp [(B+\alpha) T]-1 /$ $\exp [(B+\alpha) T]+\beta / \alpha . T$ is $\left\{\left(t-t^{*}\right)+\left(t+t^{*}\right)\right\} / 2$, where $t$ is the current time period and $t^{*}$ is the time at which cholesterol information begins to affect egg consumption. $T$ is thus zero until period $t^{*}$ and $1,2,3$, etc. thereafter. $t^{*}, \beta$, and $\alpha$ are coefficients estimated using nonlinear regression. struct a measure of information which may have strongly affected consumer taste for the product. This paper describes the construction of a measure of cholesterol information available to physicians and investigates how this information has affected consumer demand for shell eggs.

\section{Cholesterol Information}

The links between cholesterol in the diet and heart disease developed gradually since at least 1963. Initial epidemiological studies linking populations with high fat diets to a high incidence of heart disease (Kato et al.) were countered by other epidemiological studies of populations with high fat diets and a low incidence of heart disease (Biss et al.). Articles indicating a link between dietary cholesterol and blood cholesterol (reviewed by Keys, Grande, and Anderson) were countered by articles that argued against the link (Reiser, Allard et al., Albrink). Even the 1972 joint policy statement by the American Medical Association Council on Foods and Nutrition and the Food and Nutrition Board of the National Academy of Sciences, while recommending that those with elevated blood cholesterol lower their cholesterol consumption, recommended that "high priority be given to the conduct of studies that will determine reliably the extent to which the modification of plasma lipids, by dietary or other means, . . . can reduce the risks of developing coronary artery disease" (p. 1647). At the same time, controversy swirled over the link 
between blood cholesterol levels and arteriosclerosis or heart attacks (Benditt 1974, Borhani, Levy, McNamara et al.).

As clinical studies linked cholesterol in the diet to cholesterol in the blood and cholesterol in the blood with mechanisms that damage arteries, the articles in the medical literature became increasingly unambiguous about the importance for at least some part of the population of reducing one type of cholesterol in the diet (e.g., Grundy et al.). Studies of public awareness of possible danger from high cholesterol diets reflect this slow build-up of medical evidence (Scott et al., Ostrander et al.). Shekelle and Liu found that only $13 \%$ of a population sampled in 1978 were aware that too much cholesterol or fat in the diet might increase the risk of heart attacks. ${ }^{2}$

Consumers receive health information from many sources including physicians, neighbors, and the popular press. The hypothesis underlying the cholesterol index in this paper is that consumers' attitudes toward cholesterol changed slowly as scientific information accumulated, so a lagged index based on articles in medical journals could serve as a proxy for information reaching consumers from many sources. Because the diffusion of health information is a complex process (Smith, van Ravenswaay, and Thompson), this is a heroic simplification.

The cholesterol index was constructed by first scanning all articles in English dealing with humans and with clinical implications on the Medline data base. Medline is operated by Dialog Information Services. The data base includes materials from approximately 3,200 journals published in over seventy countries. It contains over four million citations for 1966 to 1987 . It does not include articles prior to 1966.

Approximately 520,000 human, English, clinical articles are contained in the Medline data base. These were scanned for any connection with cholesterol. Approximately 8,000 of these articles dealt with cholesterol. Many of these articles were considered irrelevant because they focused on smoking, obesity, alcohol abuse, or linked cholesterol with eye, joint, skin, or gall bladder disease. The 8,000 titles were therefore read, and those which did not appear relevant to the links between diet cholesterol, serum cholesterol, and heart disease or arteriosclerosis were discarded. In cases where the content was unclear from the title, the decision to include the

\footnotetext{
${ }^{2}$ One reviewer suggested that people may know something is bad for them without knowing why it is bad for them.
}

article was based on a review of the article's abstract. Approximately 1,000 such abstracts were consulted. All Scandinavian, British, and Canadian articles were discarded based on the belief that they are less likely to be read by U.S. physicians.

The numbers of articles supporting and attacking the linkage were calculated by quarter. A running total, lagged two quarters, was then calculated, with each article supporting the link adding one unit to the total and each article attacking the link subtracting one unit from the total. The equal weighting of pro and anti articles was later supported by the results of a demand equation including the number of articles supporting and the number of articles attacking the link as separate variables; their coefficients were of similar size but opposite in sign in the directions predicted. ${ }^{3}$

There are several ways to model the effect of cholesterol information apart from a simple sum. One might hypothesize that an article's influence will decline over time, as occurs with advertising campaigns. Alternatively, once a link is established, additional articles supporting that link might have little effect. An Almon lag procedure was used to investigate the lag structure of changes in the cholesterol index on egg consumption. It appears that there is a two-quarter lag before a new article has an effect on egg consumption, but the pattern of decay of influence after this initial period is unclear. Articles appear most consistently influential in the first sixteen quarters, but significant coefficients occur up to thirty-two quarters. Lacking a clearly preferable alternative, a simple sum, lagged two quarters, was used as the cholesterol information index. The cholesterol information index is given in table 1.

\section{The Egg Sector: Supply and Demand Specifications}

The supply of eggs is relatively simple to model. A pullet chick grows to production age in five months. A layer remains in production for about twelve months unless a molt and rest period are used to induce a second or third laying cycle. A low egg/feed price means a layer becomes

\footnotetext{
${ }^{3}$ The coefficient on the lagged sum of articles supporting the links between cholesterol, diet, and heart disease or arteriosclerosis was -.000245 and was different from zero at a $6 \%$ significance level. The coefficient on the lagged sum of articles attacking the links was .000524 , but it was not different from zero at a $10 \%$ significance level.
} 
Table 1. Components of the Cholesterol Information Index

\begin{tabular}{|c|c|c|c|c|c|c|c|}
\hline Year & Quarter & $\begin{array}{c}\text { Sum of Articles } \\
\text { Supporting a } \\
\text { Link }^{\mathrm{a}}\end{array}$ & $\begin{array}{c}\text { Sum of Articles } \\
\text { Questioning a } \\
\text { Link }^{\mathrm{a}}\end{array}$ & Year & Quarter & $\begin{array}{c}\text { Sum of Articles } \\
\text { Supporting a } \\
\text { Link }^{\mathbf{a}}\end{array}$ & $\begin{array}{c}\text { Sum of Articles } \\
\text { Questioning a } \\
\text { Link }^{\mathrm{a}}\end{array}$ \\
\hline \multirow[t]{3}{*}{$1955-65$} & & 0 & 0 & 1977 & 1 & 375 & 10 \\
\hline & & & & & 2 & 385 & 12 \\
\hline & & & & & 3 & 392 & 12 \\
\hline \multirow[t]{5}{*}{1966} & 1 & 0 & 0 & & 4 & 400 & 14 \\
\hline & 2 & 0 & 0 & & & & \\
\hline & 3 & 8 & 0 & 1978 & 1 & 406 & 16 \\
\hline & 4 & 15 & 0 & & 2 & 413 & 16 \\
\hline & & & & & 3 & 427 & 18 \\
\hline \multirow[t]{5}{*}{1967} & 1 & 21 & 0 & & 4 & 435 & 19 \\
\hline & 2 & 27 & 0 & & & & \\
\hline & 3 & 36 & 0 & 1979 & 1 & 442 & 19 \\
\hline & 4 & 50 & 0 & & 2 & 452 & 19 \\
\hline & & & & & 3 & 461 & 19 \\
\hline \multirow[t]{5}{*}{1968} & 1 & 61 & 0 & & 4 & 465 & 21 \\
\hline & 2 & 69 & 0 & & & & \\
\hline & 3 & 82 & 1 & 1980 & 1 & 472 & 22 \\
\hline & 4 & 87 & 1 & & 2 & 483 & 25 \\
\hline & & & & & 3 & 491 & 26 \\
\hline \multirow[t]{5}{*}{1969} & 1 & 94 & 1 & & 4 & 499 & 26 \\
\hline & 2 & 101 & 1 & & & & \\
\hline & 3 & 107 & 1 & 1981 & 1 & 508 & 26 \\
\hline & 4 & 120 & 1 & & 2 & 517 & 26 \\
\hline & & & & & 3 & 530 & 27 \\
\hline \multirow[t]{5}{*}{1970} & 1 & 125 & 1 & & 4 & 531 & 29 \\
\hline & 2 & 132 & 1 & & & & \\
\hline & 3 & 138 & 1 & 1982 & 1 & 545 & 30 \\
\hline & 4 & 143 & 1 & & 2 & 558 & 30 \\
\hline & & & & & 3 & 569 & 31 \\
\hline \multirow[t]{5}{*}{1971} & 1 & 149 & 1 & & 4 & 580 & 33 \\
\hline & 2 & 160 & 1 & & & & \\
\hline & 3 & 162 & 1 & 1983 & 1 & 593 & 33 \\
\hline & 4 & 168 & 1 & & 2 & 605 & 34 \\
\hline & & & & & 3 & 615 & 34 \\
\hline \multirow[t]{5}{*}{1972} & 1 & 174 & 1 & & 4 & 627 & 34 \\
\hline & 2 & 184 & 1 & & & & \\
\hline & 3 & 191 & 2 & 1984 & 1 & 646 & 34 \\
\hline & 4 & 201 & 2 & & 2 & 655 & 35 \\
\hline & & & & & 3 & 673 & 35 \\
\hline \multirow[t]{5}{*}{1973} & 1 & 210 & 2 & & 4 & 685 & 36 \\
\hline & 2 & 215 & 2 & & & & \\
\hline & 3 & 232 & 4 & 1985 & 1 & 710 & 37 \\
\hline & 4 & 239 & 4 & & 2 & 726 & 38 \\
\hline & & & & & 3 & 739 & 39 \\
\hline \multirow[t]{5}{*}{1974} & 1 & 252 & 4 & & 4 & 757 & 39 \\
\hline & 2 & 260 & 5 & & & & \\
\hline & 3 & 270 & 6 & 1986 & 1 & 777 & 39 \\
\hline & 4 & 283 & 6 & & 2 & 789 & 39 \\
\hline & & & & & 3 & 822 & 39 \\
\hline \multirow[t]{4}{*}{1975} & 1 & 292 & 6 & & 4 & 846 & 39 \\
\hline & 2 & 304 & 6 & & & & \\
\hline & 3 & 316 & 6 & 1987 & 1 & 866 & 39 \\
\hline & 4 & 334 & 7 & & 2 & 896 & 39 \\
\hline \multirow[t]{4}{*}{1976} & 1 & 339 & 7 & & & & \\
\hline & 2 & 345 & 7 & & & & \\
\hline & 3 & 355 & 8 & & & & \\
\hline & 4 & 362 & 9 & & & & \\
\hline
\end{tabular}

Note: The cholesterol information index $(\mathrm{CHOL})$ is the sum of articles supporting a link between cholesterol and arterial disease minus the sum of articles questioning such a link.

${ }^{a}$ Lagged six months. 
unprofitable at an earlier stage and is withdrawn sooner from laying. The civilian shell egg supply equation is, therefore,

$$
S_{C}=g\left(P_{C}, H, F\right),
$$

where $P_{C}$ is the real twelve-city metro price for grade A large eggs to retailers; $H$ is a twelvemonth moving total of egg type chicks hatched, lagged two quarters; and $F$ is feed cost $=.75$ (real price in $\phi / \mathrm{lb}$. of No. 2 yellow corn at Chicago) +.25 (real price in $\phi / \mathrm{lb}$. of $44 \%$ bulk soybean meal at Decatur). See appendix for data sources.

For the demand specifications, following Smith, van Ravenswaay, and Thompson, a consumer's utility function is expressed as $U(X(Z(N)))$, where $X$ is a vector of goods with qualities $Z$, and $N$ is information which affects a consumer's perception of the quality of a set of goods. Let consumers' information, $N$, be a function of the available scientific information, $I$. This yields a demand equation in which quantity demanded is a function of prices, income, and available scientific information.

Apart from own price, a reasonable demand equation should include the prices of close substitutes. It is not clear which, if any, foods are substitutes for eggs. Huang and Haidacher and Chavas and Johnson found meat a significant substitute, but George and King, Schrader et al., and Stillman did not. Because some investigators have found significant relationships, the price of meat will be included in the demand equation. Most eggs are eaten at breakfast; therefore, bakery and cereals products are also possible substitutes. However, Putler tested and discarded them in his egg demand model, so they were not used in this model.

The cholesterol information index described above represents the available scientific knowledge. Two other variables which reflect changing tastes are also included in the demand equation: percentage of women in the workforce and time. Stillman suggested that the increase in the percentage of women working outside the home may have reduced the quantity of eggs served for breakfast at home because of time constraints. On the other hand, more working women might mean more breakfasts eaten away from home. Surveys for the American Egg Board indicate that egg consumption away from home has been increasing since the late $1970 \mathrm{~s}$. Although the anticipated relationship is ambivalent, quarterly values for the percentage of women who are in the labor market, $W W$, represent this structural change.
Time is the black box of structural change. Its use indicates a recognition of structural change without the ability to identify, or perhaps obtain data on, the cause. The time variable here is the number of the quarter from 1 in the third quarter of 1955 to 128 in the second quarter of 1987.

The civilian demand for shell eggs used in this analysis is ${ }^{4}$

$$
\begin{array}{r}
D_{C}=f\left(P_{C}, P_{S}, Y_{C}, Q_{2},\right. \\
\left.Q_{3}, Q_{4}, C H O L, W W, T I M E\right),
\end{array}
$$

where $D_{C}$ is the civilian disappearance of shell eggs (production - change in stocks - hatching use - eggs broken + imports - exports - military use); $P_{C}$ is the real twelve-city metro price for grade A large eggs to retailers; $P_{S}$ is the real price of meat; $Y_{C}$ is real civilian per capita income; $Q_{2}, Q_{3}, Q_{4}$ are quarterly dummies to account for changes in seasonal demand; $C H O L$ is the cholesterol information index; $W W$ is the percentage of women in the labor force; and TIME is the quarter number.

\section{Estimation Results}

The estimation results reported in this section represent model specifications for both constant and changing coefficients.

\section{Constant Coefficients}

Supply and demand equations were expressed in per capita terms and assumed to be variants of a double $\log$. The resulting equations are:

$$
\begin{aligned}
\log \left(S_{C} / N\right)= & C_{0}+C_{1} \log P_{C} \\
& +C_{2} \log H+C_{3} \log F, \text { and } \\
\log \left(D_{C} / N\right)= & b_{0}+b_{1} \log P_{C} \\
& +b_{2} \log P_{S}+b_{3} \log Y_{C} \\
& +b_{4} Q_{2}+b_{5} Q_{3}+b_{6} Q_{4} \\
& +\sum_{k} b_{k} \text { structural variable }{ }_{k}
\end{aligned}
$$

\footnotetext{
${ }^{4}$ Military demand, exports and imports, and eggs for breaking are not estimated in this study. The military have historically consumed more eggs per capita and are unlikely to be affected in the same way by structural change. Military consumption has recently averaged less than $1 / 2 \%$ of total egg production. Exports and imports are typically less than $2 \%$ of egg production, and they are heavily influenced by policies in other nations. Eggs for breaking are sold liquid, dried, or frozen to food manufacturers and food service institutions. Unlike shell eggs, this demand has increased since 1955 . The price of eggs for breaking is highly correlated with the price of shell eggs.
} 
The demand equation was estimated using weighted two-stage least squares as described by Kmenta (pp. 705-8) to correct for simultaneity and first-degree autocorrelation. The BoxCox transformation technique was used to test the appropriateness of the double-log form. The results supported the use of a loglinear form rather than a linear form. ${ }^{5}$

The results for all possible combinations of structural change variables are shown in table 2 . These combinations allow one to observe the effect of removing various structural variables on the size and sign of the remaining coefficients.

Initially, egg demand was estimated using data from 1966-87, the period in which the cholesterol information index could be calculated. However, severe multicolinearity occurred between time and women in the workforce, time and income, and time and the cholesterol information index ( $\rho$ greater than .98 for all). Thus, egg demand was reestimated using data from 1955 to 1987 assuming that the cholesterol information index was zero prior to 1966 . This

\footnotetext{
${ }^{5}$ The Box-Cox power transformation is $y(\lambda)=$ $\left\{\begin{array}{ll}\left(y^{\lambda}-1\right) / \lambda & \lambda \neq 0 \\ \ln y & \lambda=0\end{array}\right\}$. The log-likelihood function for $\lambda=1$, the linear transformation, was -80.1 . The loglikelihood function for $\lambda$ $=0$, the log transformation, was -42.7 .
}

assumption seems permissible given Putler's estimate, using 1960-85 quarterly data and a nonlinear time trend, that cholesterol concerns first began to have an effect in 1969. Table 3 shows the Pearson correlation coefficients for this expanded data set. Large correlations still occur between income and time, women working and time, and women working and the cholesterol information index; however, the problem is less severe than when only 1966-87 data were used.

Price is expected to have a negative effect on per capita egg demand. Huang and Haidacher recently obtained an annual own-price elasticity of -.14 . Other own-price estimates, summarized in Chavas and Johnson, range from - .092 to -.40 . This study's quarterly own-price elasticity ranged from -.02 to -.17 . depending on the structural variables included in the equation. The model with all structural variables included had an own-price elasticity ( -.17$)$ similar to Huang and Haidacher's and significantly different from zero at the $1 \%$ level.

The expected sign on the income coefficient is not clear a priori. Huang and Haidacher obtained an annual expenditure elasticity of -.06 , but it was not significantly different from zero. This study obtained a negative income elasticity for 1966-87 which was not different from zero at a 5\% significance level. The income elasticity

Table 2. Regression Coefficients for Per Capita Civilian Shell Egg Demand with Different Shifter Variables Included; 1955-87 and 1966-87 Data

\begin{tabular}{|c|c|c|c|c|c|c|c|}
\hline & $T I M E$ & $W W$ & CHOL & $\ln P_{c}$ & $\ln Y_{c}$ & $\begin{array}{c}\ln M e a t \\
\text { Price }\end{array}$ & $\bar{R}^{2}$ \\
\hline $\begin{array}{l}\text { No } \\
\text { structural } \\
\text { variables }\end{array}$ & & & & -.022 & $-.50 * * *^{\mathrm{a}}$ & .004 & .898 \\
\hline $\begin{array}{l}\text { One } \\
\text { structural } \\
\text { variable }\end{array}$ & $-.0055^{* * *}$ & $-.010^{* * *}$ & $-.00031 * * *$ & $\begin{array}{l}-.094 \\
-.043 \\
-.089\end{array}$ & $\begin{array}{c}.24 \\
-.35^{* * *} \\
-.29^{* * *}\end{array}$ & $\begin{array}{l}.053 \\
.040 \\
.054\end{array}$ & $\begin{array}{l}.960 \\
.922 \\
.932\end{array}$ \\
\hline $\begin{array}{l}\text { Two } \\
\text { structural } \\
\text { variables }\end{array}$ & $\begin{array}{l}-.0055^{* * *} \\
-.0056^{* * *}\end{array}$ & $\begin{array}{l}-.004 * \\
-.004 * * *\end{array}$ & $\begin{array}{l}-.00014 * * * \\
-.00026^{* *}\end{array}$ & $\begin{array}{l}-.129 * * \\
-.164^{* * *} \\
-.109\end{array}$ & $\begin{array}{r}.28 * * * \\
.33 * * * \\
-.27 * * *\end{array}$ & $\begin{array}{l}.082 \\
.099 \\
.078\end{array}$ & $\begin{array}{l}.960 \\
.968 \\
.932\end{array}$ \\
\hline $\begin{array}{l}\text { All } \\
\text { structural }\end{array}$ & $-.0059 * * *$ & .0018 & $-.00017 * * *$ & $-.17 * * *$ & $.35 * * *$ & $.102 *$ & .968 \\
\hline
\end{tabular}

Regression Coefficients for Per Capita Shell Egg Demand: 1966-87 Data

All

\begin{tabular}{lllllll}
$\begin{array}{l}\text { structural } \\
\text { variables }\end{array}$ & $-.0029 * * *$ & $.010^{* * *}$ & $-.00027 * *$ & $-.067 *$ & -.11 & .033 \\
\hline
\end{tabular}

${ }^{a}$ Single asterisk indicates significant at the $10 \%$ level; double asterisk indicates significant at the $5 \%$ level; triple asterisk indicates significant at the $1 \%$ level. 
Table 3. Pearson Correlation Coefficients, 1955-87 Data

\begin{tabular}{lrrrrrr}
\hline & & & & & & \\
& $\ln P_{c}$ & $\ln Y_{c}$ & $W W$ & CHOL & Price & TIME \\
\hline $\ln P_{c}$ & 1.00 & & & & & \\
$\ln Y_{c}$ & -.83 & 1.00 & & & & \\
$W W$ & -.87 & .96 & 1.00 & & & \\
CHOL & -.86 & .93 & .98 & 1.00 & & \\
$\ln M e a t$ & & & & & & \\
$\quad$ Price & .13 & .20 & .12 & .08 & 1.00 & \\
TIME & -.86 & .99 & .98 & .95 & .15 & 1.00 \\
\hline
\end{tabular}

for 1955-87 was negative only when TIME, which is closely correlated with income in this period, was omitted from the demand equation.

Huang obtained annual cross-price elasticity estimates for eggs of .047 for beef and veal, -.02 for pork, and -.0075 for other meat; however, none of these were significantly different from zero at a $10 \%$ level. In this study, cross-price elasticities for all meat ranged from .004 to .10. Only when TIME, WW, and CHOL were included in the equation was the coefficient on meat prices different from zero at a $10 \%$ level.

The seasonal dummy variables, not shown in table 2, were significantly different from zero regardless of which structural change variables were included.

The choice among structural change variables is difficult. Before considering the empirical results, one can argue that both $W W$ and $C H O L$ have changed the demand for eggs, and that other structural changes could best be captured by $T I M E$. Moreover, the effects of the different structural variables would be difficult to distinguish empirically because they, along with per capita egg consumption and per capita real income, are all strongly trended variables in the sample period.

The $\bar{R}^{2}$ is highest if two or three shifters are included in the demand equation, but the differences in $\bar{R}^{2}$ are not great once one shifter is included. The coefficients on TIME and CHOL are both consistently and significantly negative. The coefficient on women in the workforce for $1955-87$ is only significant at a $5 \%$ level if $\mathrm{CHOL}$ is omitted from the equation. Moreover, its omission does not greatly affect the signs, sizes, or significance levels of the other variables in the equation for this period. However, the coefficient on women in the workforce is positive and different from zero at a $1 \%$ significance level for 1966-87.

When nonnested hypothesis tests (Kmenta, pp. 595-98) were used to compare equations with two structural variables, none of the equations dominated another. The predicted value from each equation was significant at the $1 \%$ level in every other equation. This result suggests that all three structural variables should be included in an egg demand model.

Estimation of the demand equation with all structural change variables included for 195587 indicates that cholesterol information had decreased per capita shell egg consumption by $16 \%$ by the first quarter of 1987 . Estimation using only the 1966-87 period indicates that cholesterol information had decreased per capita shell egg consumption by $25 \%$ by the first quarter of 1987.

A recursive estimation technique was used on the equation containing all structural change variables to explore the stability of the $C H O L$ coefficient over time (Brown, Durbin, and Evans; Dufour). The $C H O L$ coefficient was negative and different from zero at a 5\% significance level after 1974. The CHOL coefficient declined in absolute value after 1983. The decline is expected if additional medical articles on cholesterol began to have a declining effect on egg consumption. One might hypothesize that, as knowledge accumulates, the importance of new articles on cholesterol which merely confirm previous articles should decline.

The equation with all structural change variables was reestimated with the addition of the variable CHOL-SQUARED to further explore a possible declining effect of cholesterol articles. The estimated coefficient on CHOL-SQUARED was not different from zero at a $10 \%$ significance level.

\section{Changing Coefficients}

The effect of cholesterol information can be modeled in alternative ways. One possibility is to assume that price and income coefficients are not fixed but vary with the cholesterol index:

$$
\left(D_{c} / N\right)=b_{0} P_{c}^{b_{1}} Y^{b_{2}} P_{S}^{b_{3}} Q_{2}^{b_{4}} Q_{3}^{b_{5}} Q_{4}^{b_{6}} W W^{b_{7}} T I M E^{b_{8}},
$$

where $b_{1}=f_{1}(C H O L)$ and $b_{2}=f_{2}(C H O L)$. If one assumes that $f_{1}$ and $f_{2}$ are simple linear functions: $b_{1}=a_{0}+a_{1} C H O L$ and $b_{2}=d_{0}+d_{1} C H O L$, taking logs of both sides yields equation (6).

(6)

$$
\begin{gathered}
\ln \left(D_{c} / N\right)=b_{0}+a_{0} \ln P_{c}+a_{1}(C H O L \\
\left.\cdot \ln P_{c}\right)+d_{0} \ln Y_{c}+d_{1}\left(C H O L \cdot \ln Y_{c}\right) \\
+b_{3} P_{S}+b_{4} Q_{2}+b_{5} Q_{3}+b_{6} Q_{4}+b_{7} W W \\
+b_{8} \ln M e a t \text { Price }+b_{9} T I M E .
\end{gathered}
$$


When estimated using the 1955-87 data, this specification yielded

$$
\text { (7) } \begin{gathered}
\ln \left(D_{c} / N\right)=2.04-.265 \ln P_{c} \\
(3.00)(-3.3) \\
-.007 \text { TIME }+.355 \ln Y_{c}-.069 Q_{2} \\
(-6.7) \quad(4.4) \quad(-8.4) \\
-.049 Q_{3}+.020 Q_{4}+.004 W W \\
(-10.5) \quad(5.4) \quad(1.5) \\
+.096 \ln \text { meat price }+.00017\left(\ln P_{c} \cdot C H O L\right) \\
(2.0) \quad(1.8) \\
-.00009\left(\ln Y_{c} \cdot C H O L\right), \\
(-2.2)
\end{gathered}
$$

where $t$-statistics are in parentheses. The coefficients on the interaction terms $\left(P_{c} \cdot C H O L\right)$ and $Y \cdot C H O L)$ are different from zero at, respectively, $10 \%$ and $5 \%$ significance levels.

The positive interaction of egg price and cholesterol seems to indicate that cholesterol information has decreased the absolute price elasticity of shell eggs in this period. As real egg prices dropped, egg consumption increased less than would be the case without cholesterol information. The negative interaction of income and cholesterol suggests that cholesterol information has also decreased the income elasticity of shell eggs in this period. As income rose, egg consumption increased less than would have occured without cholesterol information. According to these results, cholesterol information decreased per capita egg consumption by $16 \%$ by the second quarter of 1987 using 1955-87 data.

\section{Conclusions}

This paper described the construction of a cholesterol information index based on citations of the link between cholesterol and arterial disease in medical journals. When the index was used to predict per capita shell egg demand in a fixed coefficients regression, its coefficient was always negative and different from zero at a $1 \%$ significance level regardless of other variables included in the regression. Moreover, the resulting estimates of price and income elasticities were plausible. In a variable coefficients model which specified price and income elasticities as functions of cholesterol information, the presence of cholesterol information decreased the absolute own-price and income elasticities of the demand for shell eggs. As egg prices dropped, shell egg consumption increased less than would have been the case without the cholesterol in- formation. Similarly, as income rose, consumption increased less than it would have without cholesterol information. Thus, information about cholesterol appears to have had a substantial effect, decreasing per capita civilian shell egg consumption by $16 \%$ to $25 \%$ by the first quarter of 1987 , depending on the data period used.

A logical extension of this analysis would consider the performance of the cholesterol index in demand equations for red meat and poultry, for various fats, and for dairy products; these products may also have experienced structural changes in demand as consumers' information about cholesterol changed. This study provides evidence that the stock and dissemination of health information may need to be considered when food demands are estimated.

\section{[Received July 1988; final revision received October 1989.]}

\section{References}

Ahrens, E. H., Jr. "The Management of Hyperlipidemia: Whether, Rather Than How." Ann. Internal Med. 85(1976):87-93.

Albrink, Margaret. "Serum Lipids, Diet, and Cardiovascular Disease." Postgrad. Med. 55(1974):87-92.

Allard, Claude, Claude Goulet, Claude Grondin, Jaques Lesperance, and Martial Bourassa. "Patency of Autocoronary Vein Grafts and Serum Triglycerides." Amer. J. Cardiol. 33(1974):679-80.

American Egg Board. Executive summaries of attitude tracking studies, various years 1977-86.

Baker, Allen, and Eunice Armstrong. Poultry and Egg Statistics, 1960-85. Washington DC: U.S. Department of Agriculture, Econ. Res. Serv. Statist. Bull. No. 747, Dec. 1986.

Benditt, Earl P. "Evidence for a Monoclonal Origin of $\mathrm{Hu}$ man Atherosclerotic Plaques and Some Implications." Circulation 50(1977):650-52.

Biss, K., K. J. Ho, B. Mikkelson, L. Lewis, and C. B. Taylor. "Some Unique Biologic Characteristics of the Masai of East Africa." New Eng. J. Med. 284(1971):694-99.

Borhani, N. "Primary Prevention of Heart Disease: A Critique." Amer. J. Cardiol. 40(1977):251-59.

Brown, R. L., J. Durbin, and J. M. Evans. "Techniques for Testing the Constancy of Regression Relationships Over Time." J. Royal Statist. Soc. Series B, Methodology, 37(1975):149-63.

Chavas, Jean-Paul, and S. R. Johnson. "An Econometric Model of the U.S. Egg Industry." Appl. Econometrics 13(1981):321-35.

Council on Foods and Nutrition. "Diet and Coronary Heart Disease: A Council Statement.” J. Amer. Med. Assoc. 222(1970): 1647.

Dufour, Jean-Marie. "Recursive Stability Analysis of Lin- 
ear Regression Relationships." J. Econometrics 19(1982):31-76.

George, P. S., and G. A. King. Consumer Demand for Food Commodities in the United States with Projections for 1980. California Agr. Exp. Sta. Giannini Monograph No. 26, March 1971.

Grundy, S. M., P. Greenland, A. Herd, J. A. Huebsch, R. J. Jones, J. Mitchell, and R. C. Schlant. "Cardiovascular and Risk Factor Evaluation of Healthy American Adults: A Statement for Physicians by an Ad Hoc Committee Appointed by the Steering Committee, American Heart Association." Circulation 75(1987): 1340A-1362A.

Huang, Kuo S. U.S. Demand for Food: A Complete System of Price and Income Effects. Washington DC: U.S. Department of Agriculture, Econ. Res. Serv. Tech. Bull. No. 1714, Dec. 1985.

Huang, Kuo S., and Richard C. Haidacher. "Estimation of a Composite Food Demand System for the United States." J. Bus. and Econ. Statist. 1(1983):285-91.

Kato, H., J. Tillotson, M. Z. Nichaman, G. G. Rhoads, and H. B. Hamilton. "Epidemiological Studies of Coronary Heart Disease and Stroke in Japanese Men Living in Japan, Hawaii, and California." Amer. J. Epidemiol. 97(1973):372-85.

Keys, Ancel, Francisco Grande, and Joseph T. Anderson. "Bias and Misrepresentation Revisited: Perspective on Saturated Fat." Amer. J. Clinical Nutrition 27(1974):188-212.

Kmenta, Jan. Elements of Econometrics, 2nd ed. New York: Macmillan Co., 1986.

Levy, R. I. "Current Status of the Cholesterol Controversy." Amer. J. Med. 74(1983):1-4.

McNamara, D. J., R. Kolb, T. S. Parker, H. Batwin, P. Samuel, C. D. Brown, and E. Ahrens. "Heterogeneity of Cholesterol Homostasis in Man: Response to Changes in Dietary Fat Quality and Cholesterol Quantity." $J$. Clinical Investigation 79(1987):1729-38.

Ostrander, J., C. Martinsen, J. McCullough, and M. Childs. "Egg Substitutes: Use and Preference-With and Without Nutritional Information." J. Amer. Diet. Assoc. 70(1977):267-69.

\section{Appendix}

\section{Other Data Sources}

$D_{c} \quad$ Civilian disappearance of shell eggs

$H \quad$ Twelve-month moving total of eggs type chicks hatched

$P_{c} \quad$ Twelve-city metro real price for Grade A large eggs to retailers

$Y_{c} \quad$ Per capita real income

WW Percent of female noninstitutionalized population in the labor force

F $\quad$ Feed cost

$P_{S} \quad$ Real meat price index
Putler, Daniel S. The Effect of Health Information on Shell Egg Consumption. Dep. Agr. and Resour. Econ. Work. Pap. No. 448, California Agr. Exp. Sta., Aug. 1987.

Reiser, R. "Saturated Fat in the Diet and Serum Cholesterol Concentration: A Critical Examination of the Literature." Amer. J. Clinical Nutrition 26(1973):524.

Schrader, Lee F., and David A. Bessler. "A Short-Term Egg Price Forecasting Model." Paper presented at Applied Commodity Price Analysis and Forecasting, Iowa State University, Ames, 12-13 Oct. 1981.

Schrader, Lee F., Henry E. Lanzelere, George B. Rogers, and Olan Forker. The Egg Subsector of U.S. Agriculture: A Review of Organization and Performance. N. Cent. Reg. Res. Pub. No. 258, NC-117 Monograph No. 6, June 1978.

Scott, L. W., J. Foreyt, E. Manis, M. O'Malley, and A. Gotto. "A Low-Cholesterol Menu in a Steak Restaurant." J. Amer. Diet. Assoc. 24(1979):54-56.

Shekelle, R. B., and S. Liu. "Public Beliefs About Causes and Prevention of Heart Attacks." J. Amer. Med. Assoc. 240(1978):756-58.

Smith, Mark E., Eileen O. van Ravenswaay, and Stanley R. Thompson. "Sales Loss Determination in Food Contamination Incidents: An Application to Milk Bans in Hawaii. Amer. J. Agr. Econ. 70(1988):513-20.

Stillman, Richard P. A Quarterly Forecasting Model of the U.S. Egg Sector. Washington DC: U.S. Department of Agriculture Econ. Res. Serv. Tech. Bull. No. 1729, Sept. 1987.

Stone, J. R. N. The Measurement of Consumers' Expenditure and Behavior in the United Kingdom, 1920-1938. Cambridge: Cambridge University Press, 1954.

U.S. Department of Agriculture. Egg and Poultry Statistics Through Mid-1961. Statist. Bull. No. 305, Washington DC, March 1962.

U.S. Department of Agriculture, Econ. Res. Serv. Egg and Poultry Statistics Through Mid-1972. Statist. Bull. No. 525, Washington DC, Feb. 1974.

Weimer, Mark R., and Shauna Cromer. U.S. Egg and Poultry Statistical Series, 1960-87. Washington DC: U.S. Department of Agriculture, Econ. Res. Serv. Statist. Bull. No. 775, Apr. 1989.

Livestock and Poultry: Situation and Outlook

Livestock and Poultry: Situation and Outlook

Calculated from unpublished USDA data and Egg and Poultry Statistics Through Mid-1972

Calculated from data in Survey of Current Business

Bureau of Labor Statistics, Employment and Earnings and Monthly Report on the Labor Force

Calculated from data in Grain and Feed Market News and Fats and Oils Situation

Monthly Labor Review 
http://www.jstor.org

\title{
LINKED CITATIONS \\ - Page 1 of 1 -
}

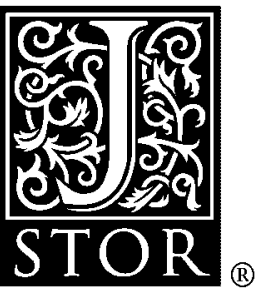

You have printed the following article:

\section{Cholesterol Information and Shell Egg Consumption}

Deborah J. Brown; Lee F. Schrader

American Journal of Agricultural Economics, Vol. 72, No. 3. (Aug., 1990), pp. 548-555.

Stable URL:

http://links.jstor.org/sici?sici=0002-9092\%28199008\%2972\%3A3\%3C548\%3ACIASEC\%3E2.0.CO\%3B2-F

This article references the following linked citations. If you are trying to access articles from an off-campus location, you may be required to first logon via your library web site to access JSTOR. Please visit your library's website or contact a librarian to learn about options for remote access to JSTOR.

\section{References}

\section{Estimation of a Composite Food Demand System for the United States}

Kuo S. Huang; Richard C. Haidacher

Journal of Business \& Economic Statistics, Vol. 1, No. 4. (Oct., 1983), pp. 285-291.

Stable URL:

http://links.jstor.org/sici?sici=0735-0015\%28198310\%291\%3A4\%3C285\%3AEOACFD\%3E2.0.CO\%3B2-Q

\author{
Sales Loss Determination in Food Contamination Incidents: An Application to Milk Bans in \\ Hawaii \\ Mark E. Smith; Eileen O. van Ravenswaay; Stanley R. Thompson \\ American Journal of Agricultural Economics, Vol. 70, No. 3. (Aug., 1988), pp. 513-520. \\ Stable URL: \\ http://links.jstor.org/sici?sici=0002-9092\%28198808\%2970\%3A3\%3C513\%3ASLDIFC\%3E2.0.CO\%3B2-9
}

